\title{
SCARF1 wt Allele
}

National Cancer Institute

\section{Source}

National Cancer Institute. SCARF1 wt Allele. NCI Thesaurus. Code C106362.

Human SCARF1 wild-type allele is located in the vicinity of $17 \mathrm{p} 13.3$ and is approximately $12 \mathrm{~kb}$ in length. This allele, which encodes scaveng er receptor class F member 1 protein, is involved in the metabolism of acetylated LDL. 